by David A.T. Harper ${ }^{l}$, Jun Li $^{2}$, Axel Munnecke ${ }^{3}$, Alan W. Owen ${ }^{4}$,Thomas Servais ${ }^{5}$ and Peter M. Sheehan ${ }^{6}$

\title{
Concluding IGCP 503: Towards a holistic view of Ordovician and Silurian Earth systems
}

\author{
1 Statens Naturhistoriske Museum (Geologisk Museum), Øster Voldgade 5-7, DK-1350 København K, Denmark. E-mail: Dharper@snm.ku.dk \\ 2 Nanjing Institute of Geology and Palaeontology, Chinese Academy of Sciences, Chi-Ming-Ssu, Nanjing 210008, China \\ 3 GeoZentrum Nordbayern, Fachgruppe Paläoumwelt, Loewenichstraße 28, 91054 Erlangen, Germany \\ 4 School of Geographical \& Earth Sciences, University of Glasgow, Gregory Building, Lilybank Gardens, Glasgow G12 8QQ, Scotland, UK \\ 5 FRE 3298 CNRS-Lille1 Géosystèmes, Université de Lille1, SN5, F-59655 Villeneuve-d'Ascq Cedex, France \\ 6 Department of Geology, Milwaukee Public Museum, 800 West Wells Street, Milwaukee, Wisconsin 53233, USA
}

IGCP 503 'Ordovician Palaeogeography and Palaeoclimate' was established in 2004 primarily to identify the main drivers, both biological and geological, of the Great Ordovician Biodiversification Event. From the outset of the project it was clear that this event was part of a larger-scale, long-term, multifaceted process that included the end Ordovician extinction and Silurian recovery, if not more. IGCP 503 thus developed a major network that included scientists whose interests spanned the entire Lower Palaeozoic and encompassed a range of disciplines from classical palaeontology and palaeoecology through isotope geochemistry to climate modelling.

\section{Introduction}

IGCP 503 formally concluded at the end of 2009 but continued during 2010. In terms of its extensive network of scientists, participation in frequent, broad-ranging conferences and field excursions and its substantial output of both individual papers and thematic issues and volumes, 503 has been one of the most successful of the IGCP projects. In addition the project met the fundamental mission of UNESCO programmes by building a platform for the exchange of knowledge, especially scientific knowledge, through genuine international cooperation, capacity building in a younger generation of earth scientists and technical assistance to colleagues in developing states.

\section{The Ordovician and Silurian systems}

A fundamentally important dimension to the project was the close cooperation with the ICS subcommissions for both the Ordovician and Silurian systems. Over many years, both groups have developed an increasingly precise chronostratigraphic infrastructure, essential to map changes in biodiversity together with fluctuations in sea level and sea-water chemistry through this part of the Early Palaeozoic. In particular, during the last decade the International Subcommission on Ordovician Stratigraphy has defined three international series and seven stages, providing a solid, global chronostratigraphy for the system (Fig. 1; Bergström et al., 2009). In the 51 years since its formal ratification the subcommission has expanded from being primarily the domain of biostratigraphers to being a platform for all forms of research on Ordovician rocks and fossils and the application of a wide range of correlation techniques (Harper, 2011). The Silurian timescale consisting of four international series and seven stages has been in operation for some time but has recently been the subject of some scrutiny. The close cooperation with IGCP 503 has highlighted the importance not only of a reliable and usable international timescale but also of having accurate palaeogeographical basemaps for our systems and some consensus on the patterns and trends of changing

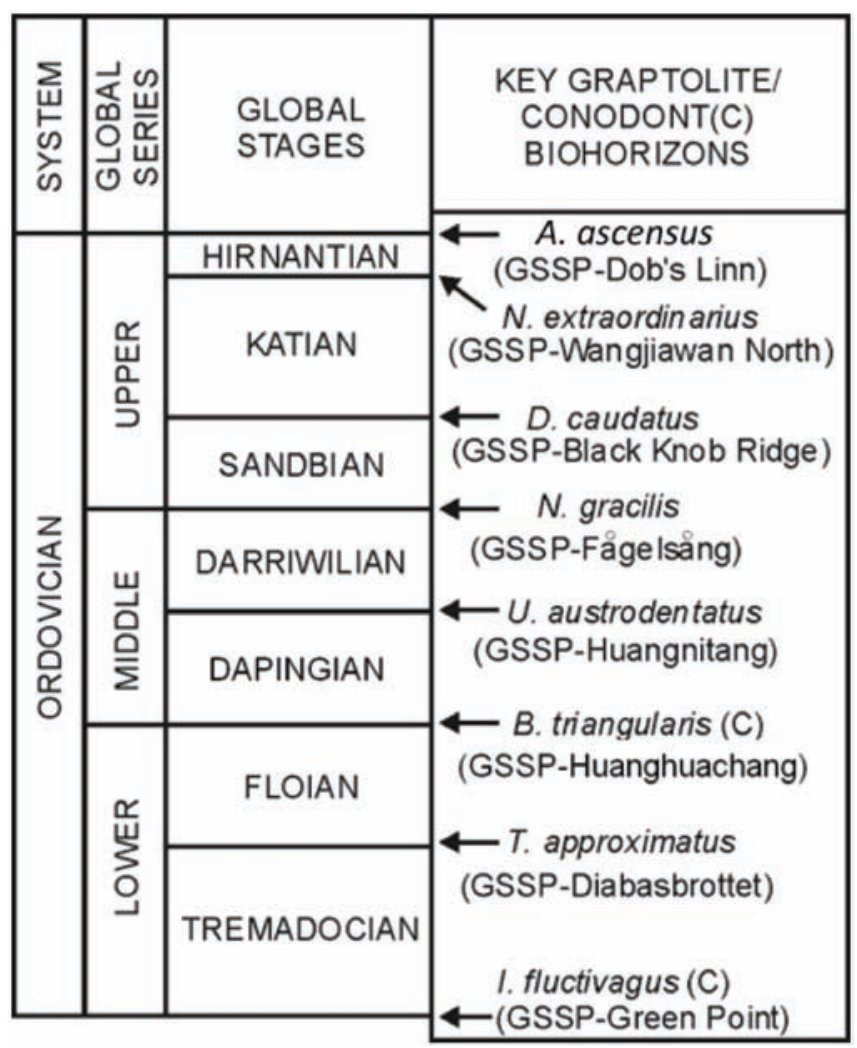

Figure 1. Ordovician chronostratigraphy (modified from various sources). 
sea level, sea-water chemistry and temperature during the Early Palaeozoic.

The distinctive conditions and environments of the Ordovician and Silurian worlds have long been recognised (e.g. Jaanusson, 1984; Holland, 1991). In contrast to the relatively empty seas of the Cambrian, modern ocean environments and their ecosystems developed during the Ordovician and Silurian periods. All the phyla were probably in place and real diversity at the lower taxonomic levels in the plankton, nekton and benthos accelerated. The two periods witnessed three major biotic events, the Great Ordovician Biodiversification Event (Webby et al., 2004a; Harper, 2006), the end-Ordovician extinction (Barnes, 1986; Rong and Chen, 1986; Rong and Harper, 1988; Barnes et al., 1995; Sheehan, 2001a) and the Early Silurian recovery (Rong and Harper, 1999). These three events together helped develop the complexity of the Palaeozoic Evolutionary Fauna and established the day-to-day pattern of marine life in the Ordovician and Silurian world (Sheehan, 2001b). Arguably during this interval both modern climates and marine ecosystems developed, establishing rules of engagement between the atmosphere, biosphere and hydrosphere of the subsequent Earth System. In general terms Palaeozoic oceans were characterised by short trophic chains dominated by suspension-feeding organisms. The composition of this ecosystem contrasted with that of the subsequent Mesozoic and Cenozoic eras, which was dominated by deposit-feeding communities linked to more bioturbated substrates; complex community structures driven by a more pervasive arms race.

\section{IGCP 503: Aims and ambitions}

There is no doubt much of our contemporary research stands on the shoulders of giants. The success of IGCP 503 thus owes a debt of gratitude to a number of previous IGCP projects. IGCP 216, Global Events in Earth History, was an ambitious project, essentially focussed on the study of abiotic (geological) events and processes that caused biological events at various chronological, ecological and evolutionary levels (Walliser, 1986). Although this spawned a subsequent related project, IGCP 335 Biotic Recovery from Mass Extinction Events (Hart, 1996), it was IGCP 410, The Great Ordovician Biodiversification Event, extending from 1997-2002 that specifically focussed on the Ordovician System (Webby et al., 2004a,b).

IGCP 410 concluded with a benchmark compendium of the patterns of biodiversity change of all the major fossil groups through the Ordovician Period (Webby et al., 2004a). It was logical that the successor project, IGCP 503, should now focus on the biological and geological triggers of these changes. Such a project would promote a more holistic approach, involving state-of-the art knowledge of sealevel change and sea-water chemistry that could be integrated with climate, biodiversity and ecosystem change through the Ordovician and Silurian systems (Fig. 2). The importance of regional successions and events was also a primary focus prompting also the necessity to generate and utilise accurate palaeogeographic reconstructions for the period (Fig. 3). The Cambrian roots of the Ordovician Biodiversification were also explored as was the potential influence of extraterrestrial events.

\section{Developing an international network}

Critical to the success of the project was its international network, comprising over 260 scientists in 35 countries drawn from both the developed and developing world, together with multinational leadership representing many different strands of Lower Paaleozoic

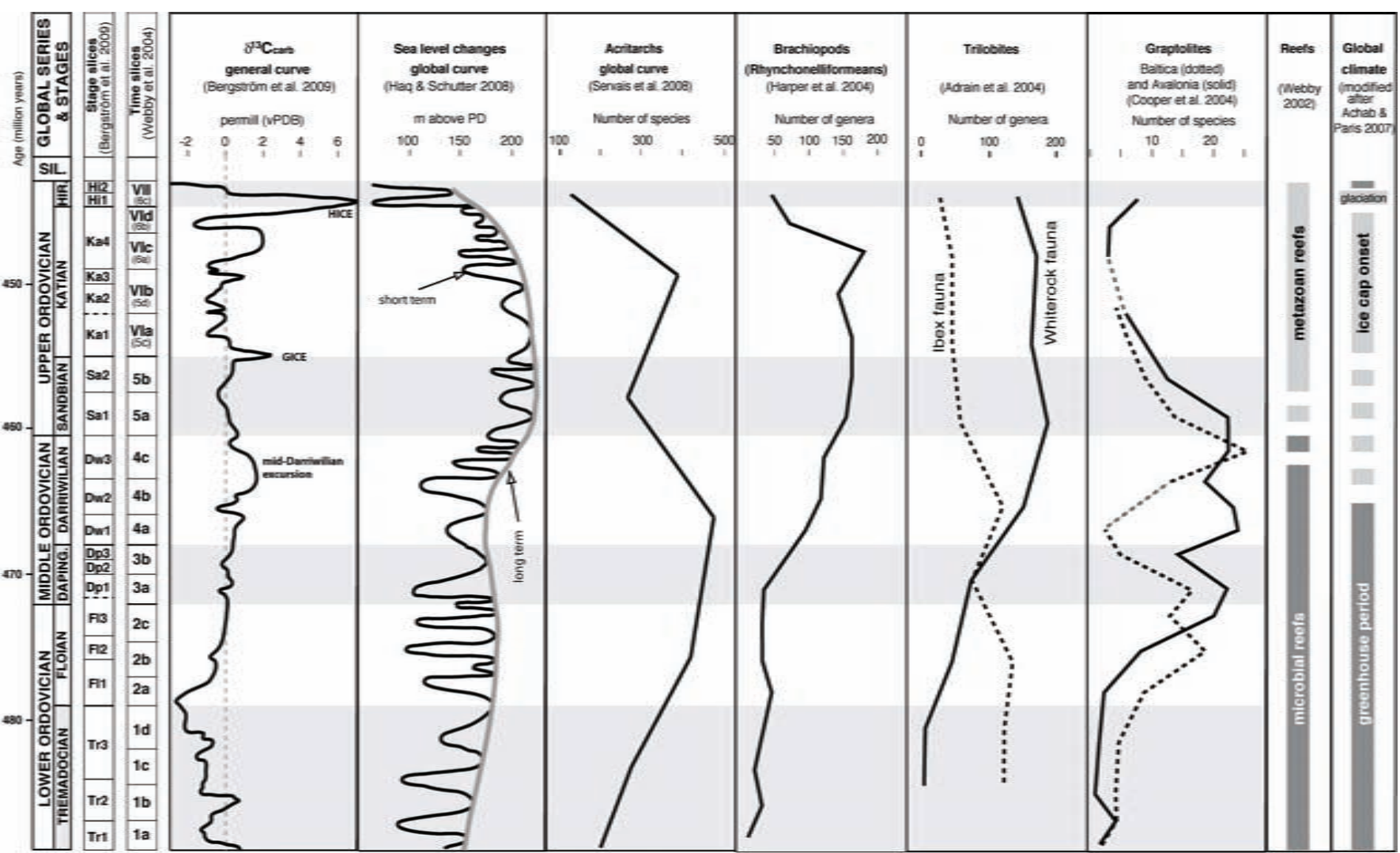

Figure 2. Biotic events, sea-level and sea-water chemistry fluctuations (modified from Servais et al., 2010 and Munnecke et al., 2010b). 


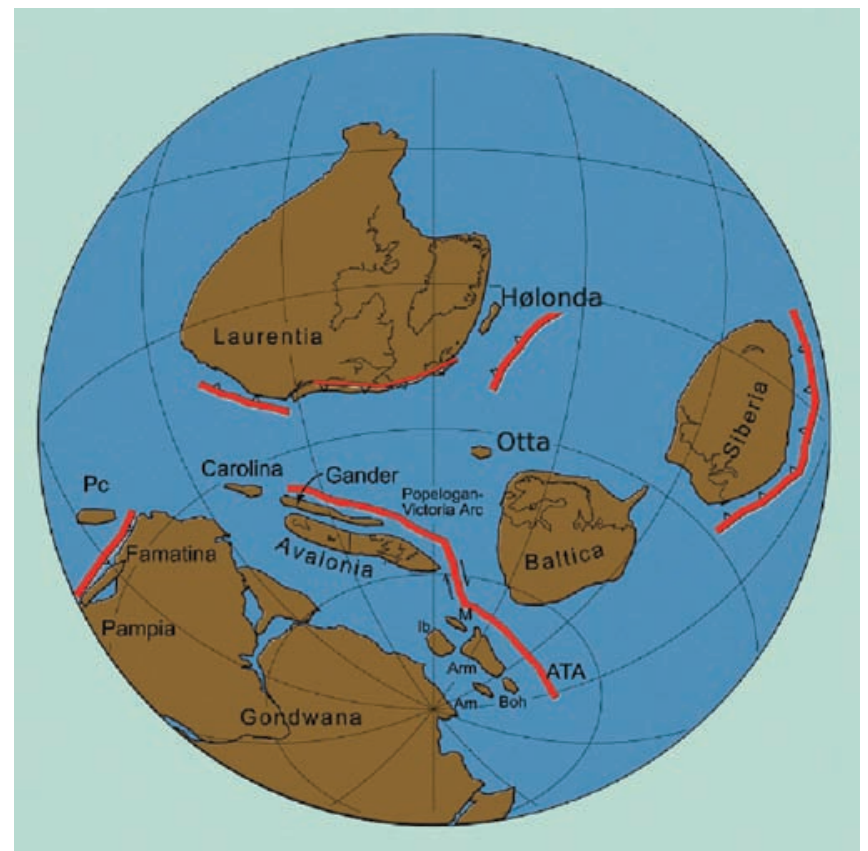

Figure 3. Ordovician palaeogeography (modified from Harper and MacNiocaill, 2002 and Harper, 2006).

geology (Fig. 4). Apart from shared experience and expertise, intensive study of regional successions was a key part of the project. Communication included a highly effective homepage maintained by Olle Hints, Tallinn University of Technology (http://www.igcp503. org/) and frequent newsletters including reports in Ordovician News and Silurian Times, but it was the wide range of meetings and field excursions directly or indirectly related to the project, some 25 in all, that generated and sustained IGCP 503's large scientific network. In particular the following six conferences or thematic sessions were a key part of the meeting programme:

(a) September 2004, official opening meeting at Erlangen, Germany (Fig. 5): ocean and climate modelling, and the development of stable C- and O-isotopes (Munnecke and Servais, 2007); field meeting Southern Sweden (Fågelsång [Fig. 6], Öland, Gotland);

(b) July 2005, meeting at Milwaukee, Wisconsin, USA: evolutionary palaeoecology, onshore-offshore transects; field excursions in the Cincinnati and Wisconsin areas;

(c) August 2006, meeting at Glasgow, Scotland, UK: changing palaeobiodiversity and palaeobiogeographical patterns (Owen, 2008); field excursions in southern Scotland;

(d) August 2007, 10th International Symposium of the Ordovician System, 3rd International Symposium of the Silurian System, in conjunction with the IGCP 503 meeting at Nanjing: biological and geological events together with refinement of the stratigraphical framework; field excursions to East and Southeast China;

(e) August 2008, closing meeting at Lille, France: major focus on Palaeozoic palaeoclimates and a final synthesis (Munnecke et al., 2010a; Servais and Owen, 2010); field meeting in Belgium;

(f) August-September 2009, absolutely final meeting in Copenhagen, with a large part dedicated to biogeographical patterns of Early Palaeozoic biotas (Harper and Servais, in press); field meeting in Sweden and Norway.

\section{Published scientific outcomes and outreach}

The scientific output of the project, comprising several hundred published papers is, of course, difficult to summarise, succinctly. Nevertheless a list of many of the publications is available on the project homepage (http://www.igcp503.org/). In addition, five special issues of journals or other publication series have published results of project 503, including some of the major advances presented at the main annual meetings (Munnecke and Servais, 2007; Owen, 2008; Servais and Owen, 2010; Munnecke et al., 2010a; Harper and Servais, in press). Moreover in a series of review papers, Servais et al. (2009, 2010) and Munnecke et al. (2010b) have reviewed many results of the project. In addition to the primary scientific literature, work on the Great Ordovician Biodiversification Event has featured in several popular science articles (e.g. O'Donoghue, 2008; Harper, 2009; Catchpole, 2011). The asteroid impact hypothesis, though controversial, has formed the main theme of a recent popular book on the beneficial effects of meteorite strikes (Nield, 2011). The scientific results have formed the basis for many popular lectures by members of the project and many newspaper articles and radio interviews.

\section{The story so far}

Early Palaeozoic biodiversifications in most marine groups of organisms were spectacular and undoubtedly sustained, forming the ground rules for subsequent marine life on the planet. The majority of invertebrate animal phyla appeared at about the beginning of the Palaeozoic (Budd, 2008), mostly during the Cambrian Explosion but it was the Ordovician Radiation that generated diversity within these phyla and established an ecosystem that survived the entire Palaeozoic Era, through some 250 million years of Earth history. The Cambrian ecosystem may have been quite different from those that followed during the Ordovician and Silurian periods and was characterised by relatively few megaguilds, weakly-structured communities and a relatively sterile water column (Droser and Sheehan, 1997; Harper, 2006). The change between the Cambrian and Ordovician worlds was a major turning point in Earth history; the late Cambrian was characterised by warm oceans with widespread anoxia and dysoxia and probably low saturation states for calcite and aragonite (Pruss et al., 2010). Despite the appearance of calcified skeletons in both solitary and colonial organisms in the late Neoproterozoic (Wood, 2011), the Cambrian carbonate factory was dominated by physical and microbial processes rather than by biogenic material. Carbonate build-ups and reefs were rare following the virtual extinction of the archaeocyathans in the mid Cambrian. The earliest metazoan-dominated reefs are now known from the upper Tremadocian (Adachi et al., 2011) but it was not until late Darriwilian that such reef ecosystems became dominant (Webby, 2002). It was also not until after the Tremadocian that limestones in Laurentia show a marked increase in skeletal components (Pruss et al., 2010). A general cooling trend through the Ordovician may have enhanced biodiversification (Trotter et al., 2008) and encouraged the skeletalization of larger benthic animals (Pruss et al., 2010).

The Ordovician Period experienced a massive rise in marine biodiversity (Sepkoski, 1981) accompanied by an increase in the biocomplexity of marine life (Droser and Sheehan, 1997; Servais et 


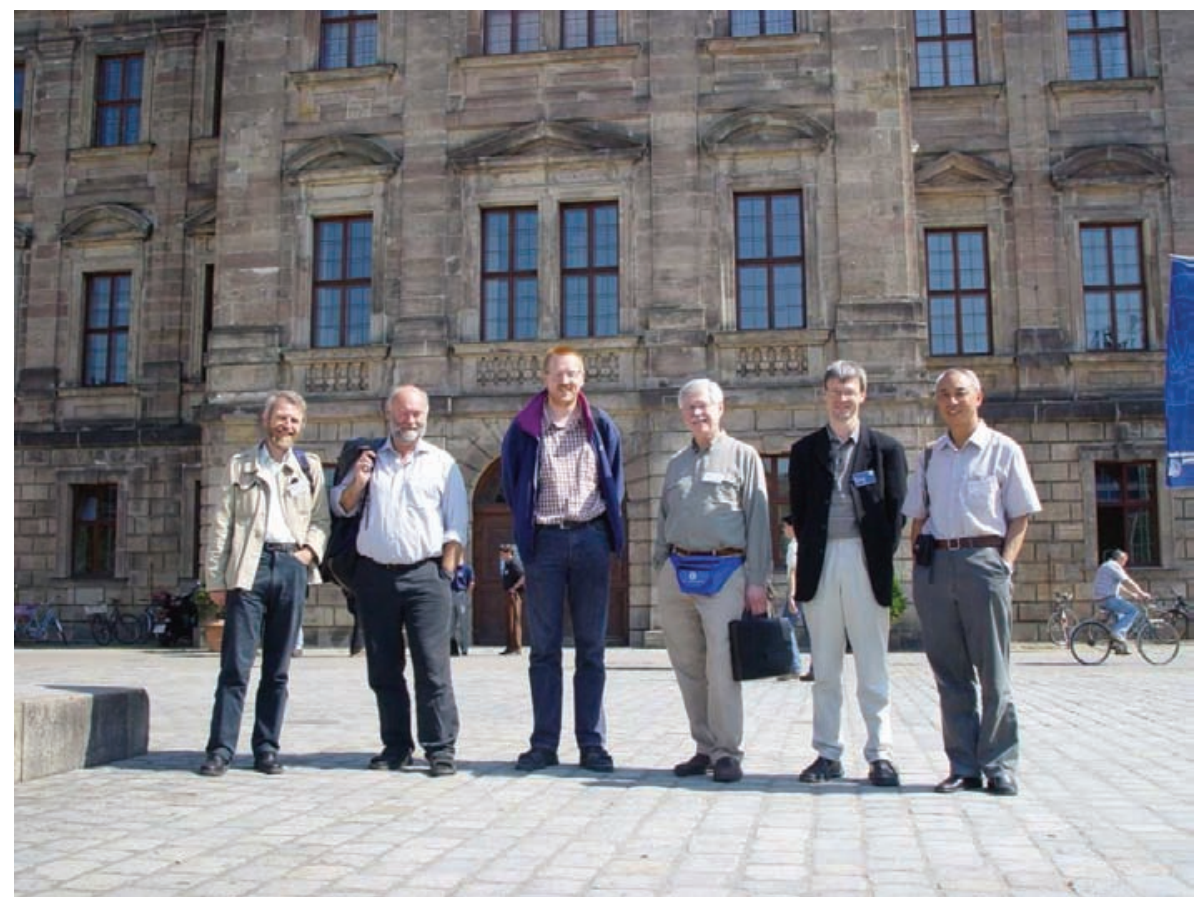

Figure 4. The group leaders in Erlangen (September 2004), suitably relaxed at the start of the project. From left to right: Alan Owen, Dave Harper, Thomas Servais, Peter Sheehan, Axel Munnecke and Jun Li.

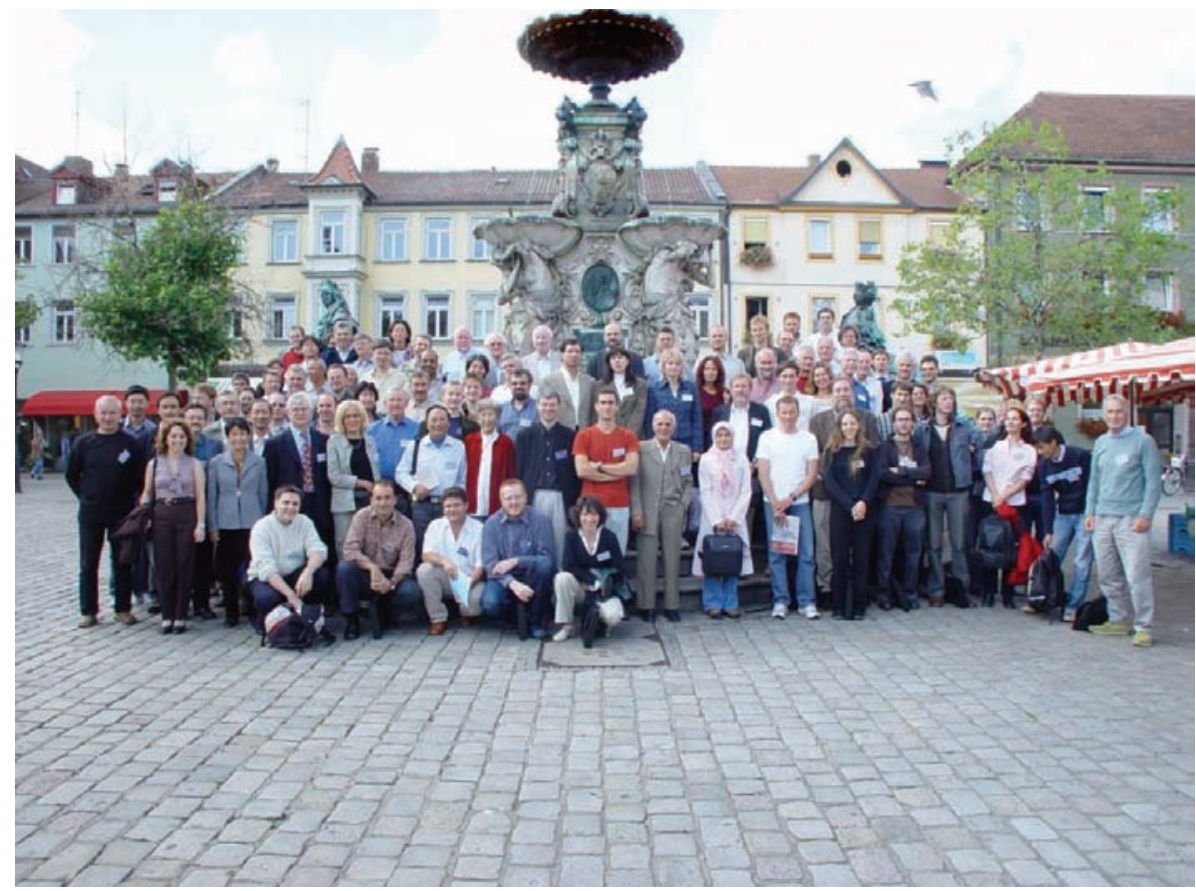

Figure 5. Group photograph of the Erlangen conference (September 2004).

al., 2010) marking 'The Great Ordovician Biodiversification Event' as one of the two most significant radiation events in the history of marine life. The unusual environments of the Ordovician Period were associated with extensive, epicontinental seas developed during sealevel high stands (Algeo and Seslavinski, 1995; Pratt and Holmden, 2008), driven by a waning greenhouse climate, flat seafloors and restricted land areas; these were probably represented by occasional, emergent archipelagos. Sea levels were most probably the highest of the Palaeozoic and possibly the highest of the entire Phanerozoic
(Hallam, 1992; Miller et al., 2005; Haq and Schutter, 2008); there are no modern analogues to the epicontinental seas of the Ordovician Period. Importantly, the extent of the tropical shelves was the greatest of the Phanerozoic (e.g. Walker et al., 2002). Magmatic and tectonic activity was intense and persistent and was associated with rapid plate movements and widespread volcanic activity. Island arcs and mountain belts provided sources for clastic sediment in competition with the carbonate belts associated with the platforms on most of the continents. Following the Neoproterozoic break-up of Rodinia, the fragmented continents reached their maximum dispersal (Cocks, 2001; Harper, 2006) driving provincialism. Such biogeographical differentiation was extreme, affecting plankton, nekton and benthos, and climatic zonation, particularly in the southern hemisphere, where most of the continental plates were situated, was pronounced. Provincial differentiation amongst the benthos was also marked with biogeographic differences persisting until near the end of the period (Williams, 1973), when these were disrupted by the end-Ordovician glaciation (Rong and Harper, 1988; Owen et al., 1991). Together these conditions were clearly ripe for allopatric (geographic) speciation processes together with opportunities for canalization of ecological niches (Harper, 2006, 2010); the scene was set for accelerating alpha, beta and gamma diversification. Another important stimulus to the radiation, particularly of the suspension-feeding benthos, was provided by diversifications at the base of the Ordovician food web. The trophic food chain revolution increased nutrient supplies through increases in the diversity, and by proxy abundance, in the phyto- and zooplankton (Servais et al., 2008) including the establishment of larval planktotrophy in a number of groups (Peterson, 2005). The stage was set for the gradual increase in ecosystem complexity that continued into the Cenozoic. The evolution of pelagic cephalopods in the Ordovician was dependent on the increased abundance of the plankton (Kröger et al., 2009). Increasingly abundant plankton permitted the gradual expansion of predation that began in the Ordovician and culminated in the diverse predators including of the Modern EF, including giant marine reptiles and mammals.

More controversial but nevertheless stimulating explanations have included the roles of "asteroids impacts" on the Mid Ordovician diversifications (Schmitz et al., 2008) and mantle plumes on the diversification and extinction events (Barnes, 2004; Lefebvre et al., 2010).

The Ordovician Period thus stands as a portal between the less 


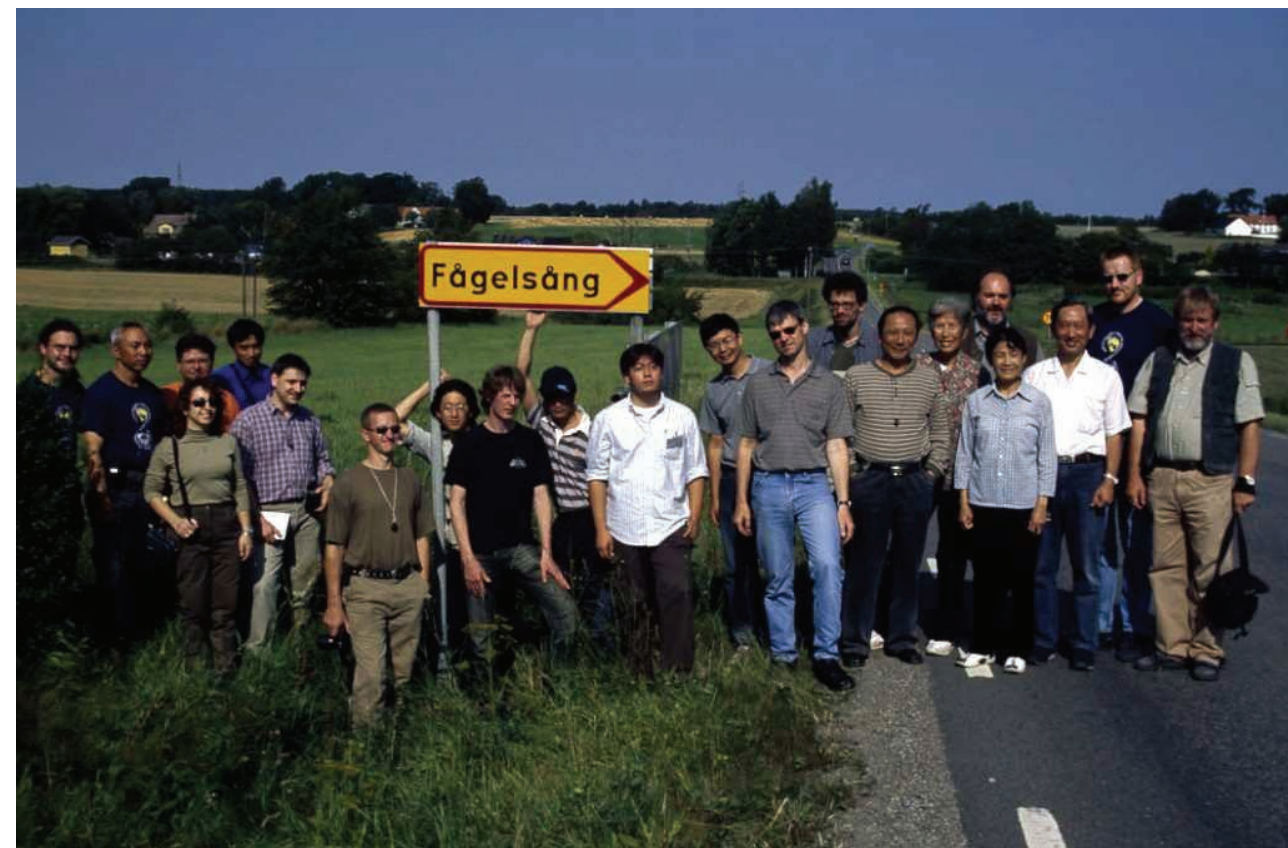

Figure 6. Group photo, field work in Sweden (September 2004).

stable biotic and environmental conditions of the Cambrian and the more modern-type climates and ecosystems of the rest of the Phanerozoic.

\section{Future directions}

During the last two decades studies on the Ordovician and Silurian systems have advanced dramatically through the acquisition of new data from many new and previously poorly-studied sections throughout the world. In particular IGCP 410, through its clade and regional teams, established a strong focus in these areas. More importantly, however, a range of new geochemical techniques and sea-level proxies applied to existing and new sections are rapidly developing our knowledge of ocean chemistry and sea level change and these are already an integral part of many research programmes. Of the great extinction events, the end Ordovician glaciations and extinctions most closely resemble modern climate change. During the Ordovician a summary by Young et al. (2010) found "... increasing $\mathrm{pCO}_{2}$ levels in response to ice-sheet expansion that reduced silicate weathering. Ultimately, the time period of elevated $\mathrm{pCO}_{2}$ levels is followed by geologic evidence of deglaciation." The increasing $\mathrm{pCO}_{2}$ levels and subsequent deglaciation produced a marine extinction that serves as a possible model for future changes in the modern oceans.

Rigorous numerical analysis of the changing palaeogeographical patterns of Ordovician zooplankton is providing a remarkably successful tool for plotting temporal changes in climate belts (Vandenbroucke et al., 2009, 2010a, b). Importantly entirely new fossil biotas continue to be found. For example, the remarkable Burgess Shale-type assemblage from the Tremadocian of Morocco reveals much on the evolution of the deeper-water communities during the initial phases of the GOBE (Van Roy et al., 2010). The results of IGCP 410 and 503 have sharpened our focus on the significance of climatic and environmental change for the evolution of Early Palaeozoic biota at a critical time in Earth history but these projects have also identified the need for the continued careful sampling of regional sections against a well-constrained biostratigraphy across a wide range of palaeolatitudes. We have highlighted too the importance of developing and applying entirely new proxies, e.g., Osmium isotopes, ${ }^{13} \mathrm{C}-$ ${ }^{18} \mathrm{O}$ 'clumped' isotopes, or Ca isotopes (Farkaš et al., 2007; Finlay et al., 2010; Finnegan et al., 2011; Tripati et al., 2010), associated with innovative analytical techniques while continuously building and supplementing our global databases from precisely assembled local and regional datasets. The integration of biotic and isotope data is emphasized by two recent publications on environmental changes at the base and the top of the Ordovician (Saltzman et al., 2011; Finnegan et al., 2011). Fluctuations in climate and environment in deep time provide the dynamic to ancient marine ecosystems, moreover the organisms themselves present important feedback processes. Essential to our understanding of Early Palaeozoic Earth systems is the continued search for links and relationships between environments, ecosystems and evolution. This can only be achieved by the multidisciplinary and multinational approach advocated by the recent IGCP 410 and 503 projects. Moreover, these and other themes will continue to be addressed in the recently approved IGCP 591 'The Early to Middle Paleozoic Revolution: Bridging the gap between the Great Ordovician Biodiversification Event and the Devonian terrestrial revolution'.

\section{Acknowledgements}

We thank the many participants of IGCP 503 from wide-ranging national and scientific backgrounds whose dedication and substantial input to the project have helped make some of the paradigm shifts and quantum leaps in our science.

\section{References}

Adachi, N., Ezaki, Y. and Liu, J., 2011, Early Ordovician shift in reef construction from microbial to metazoan reefs. Palaios, v. 26, pp. 106114.

Algeo, T.J. and Seslavinski, K.B., 1995, The Paleozoic World: Continental flooding, hypsometry, and sealevel. American Journal of Science, v. 295, pp. 787-822.

Barnes, C.R., 1986, The faunal extinction event near the Ordovician-Silurian boundary: a climatically induced crisis. Lecture Notes in Earth Sciences, v. 8 , pp. $119-126$.

Barnes, C.R., 2004, Was there an Ordovician superplume event?, in Webby, B.D., Paris, F., Droser, M. and Percival, I. (eds), The Great Ordovician Biodiversification Event, Columbia University Press, New York, pp. 7780.

Barnes, C.R., Fortey, R.A. and Williams, H., 1995, The pattern of global bioevents during the Ordovician Period, in Walliser, O.H. (ed.), Global Events and Event Stratigraphy in the Phanerozoic, Springer, Berlin, pp.139172.

Bergström, S.M., Chen, X., Gutiérrez-Marco, J.C. and Dronov, A., 2009, The new chronostratigraphic classification of the Ordovician System and 
its relations to major regional series and stages and to $\delta^{13} \mathrm{C}$ chemostratigraphy. Lethaia v. 42, pp. 97-107.

Budd G E., 2008, The earliest fossil record of the animals and its significance. Philosophical Transactions of the Royal Society, v. B 363, pp. 14251434.

Catchpole, H., 2011, Lucky Strike. Cosmos Magazine, v. 37, pp. 36-42.

Cocks, L.R.M., 2001, Ordovician and Silurian global geography. Journal of the Geological Society, London, v. 158, pp. 197-210.

Droser, M.L. and Sheehan, P.M., 1997, Palaeoecology of the Ordovician Radiation: resolution of large-scale patterns with individual clade histories, palaeogeography and environments. Geobios, v. 20, pp. 221229.

Farkaš, J., Böhm, F., Wallmann, K., Blenkinsop, J., Eisenhauer, A., van Geldern, R., Munnecke, A., Voigt, S. and Veizer, J., 2007, Calcium isotope budget of Phanerozoic oceans: Implications for chemical evolution of seawater and its causative mechanisms. Geochimica et Cosmochimica Acta, v. 71, pp. 5117-5134.

Finlay, A.J., Selby, D. and Gröcke, D.R., 2010, Tracking the Hirnantian glaciation using Os isotopes. Earth and Planetary Science Letters, v. 293, pp. 339-248.

Finnegan, S., Bergmann, K., Eiler, J.M., Jones, D.S., Fike, D.A., Eisenman, I., Hughes, N.C., Tripati, A.K. and Fischer, W.W., 2011, The magnitude and duration of Late Ordovician-Early Silurian Glaciation. Science, v. 331, pp. 903-906.

Hallam, A., 1992, Phanerozoic Sea-level Changes. Columbia University Press, New York. 266 pp.

Haq, B.U. and Schutter, S.R., 2008, A chronology of Paleozoic sea-level changes. Science, v. 322, pp. 64-68.

Harper, D.A.T., 2006, The Ordovician biodiversification: setting an agenda for marine life. Palaeogeography, Palaeoclimatology, Palaeoecology, v. 232, pp. 148-166.

Harper, D.A.T. 2009, Diversity's big bang: The Great Ordovician Biodiversification Event. GEO, v. 12, pp. 22-27.

Harper, D.A.T., 2010, The Ordovician brachiopod radiation: roles of alpha, beta and gamma diversity. Special Paper, Geological Society of America, v. 466, pp. 69-83.

Harper, D.A.T. 2011, A sixth decade of the Ordovician Period: status of the research infrastructure of a geological system, in GutiérrezMarco, J.C., Rábano, I. and García-Bellido, D. (eds.), Ordovician of the World. Cuadernos del Museo Geominero, v. 14, pp. 3-9. Instituto Geológico y Minero de España, Madrid.

Harper, D.A.T. and Mac Niocaill, C., 2002, Early Ordovician rhynchonelliformean brachiopod diversity: Comparing some platforms, margins and intra-oceanic sites around the Iapetus Ocean, in Crame, J.A. and Owen, A.W. (eds), Palaeobiogeography and Biodiversity Change: The Ordovician and Mesozoic-Cenozoic Radiations: Geological Society, London, Special Publications, v. 194, pp. 25-34.

Harper, D.A.T. and Servais, T. (eds). Early Palaeozoic biogeography and geography. Memoir, Geological Society, London. In press.

Hart, M.B. (ed.), 1996, Biotic recovery from mass extinction events. Special Publication, Geological Society, London, v. 102, 392pp.

Holland, C.H., 1991, What is so very special about the Silurian. Murchison Symposium. Special Papers in Palaeontology, v. 44, pp. 391-397.

Jaanusson, V., 1984, Ordovician benthic macrofaunal associations, in Bruton, D.L. (ed.), Aspects of the Ordovician System. Palaeontological Contributions from the University of Oslo, v. 295, pp. 127-139.

Kröger, B., Servais, T. and Zhang, Y., 2009, The Origin and Initial Rise of Pelagic Cephalopods in the Ordovician. Plos One, v. 4, e 7262, 12 pp.

Lefebvre, V., Servais, T., François, L. and Averbuch, O., 2010, Did a Katian large igneous province trigger the Late Ordovician glaciation? A hypothesis tested with a carbon cycle model. Palaeogeography, Palaeoclimatology, Palaeoecology, v. 296, pp. 310-319.

Miller, K.G., Kominz, M.A., Browning, J.V., Wright, J.D., Mountain, G.S., Katz, M.E., Sugarman, P.J., Cramer, B.S., Christie-Blick, N. and Pekar,
S.F., 2005, The Phanerozoic record of global sea-level change. Science, v. 310, pp. $1293-1298$.

Munnecke, A., Calner, M. and Harper, D.A.T.(eds), 2010a, Early Palaeozoic sea level and climate - Selected papers presented at the IGCP 503 closing meeting in Lille (France), 23-31 August 2008. Palaeogeography, Palaeoclimatology, Palaeoecology, v. 296, pp. 213-413

Munnecke, A., Calner, M., Harper, D.A.T. and Servais, T., 2010b, Ordovician and Silurian sea-water chemistry, sea level, and climate: a synopsis. Palaeogeography, Palaeoclimatology, Palaeoecology, v. 296, pp. 389413

Munnecke, A. and Servais, T. (eds.), 2007, Early Palaeozoic Palaeogeography and Palaeoclimate. Palaeogeography, Palaeoclimatology, Palaeoecology, v. 245 , pp. 316 .

Nield, T., 2011, Incoming. Or: Why We Should Learn to Stop Worrying and Love the Meteorite. Granta, $272 \mathrm{pp}$.

O’Donoghue, J., 2008, The Ordovician: Life's second big bang. New Scientist, v. 2660, pp. 34-37.

Owen, A.W. (ed.), 2008, Ordovician and Silurian environments, biogeography and biodiversity change. Lethaia, v. 41, pp. 97-194.

Owen, A.W., Harper, D.A.T. and Rong, J.-Y., 1991, Hirnantian trilobites and brachiopods in space and time. Geological Survey of Canada Paper, v. 90, pp. 179-190.

Peterson, K. J., 2005, Macroevolutionary interplay between planktic larvae and benthic predators. Geology, v. 33, pp. 929-932.

Pratt, B.R. and Holmden, C. (eds), 2008, Dynamics of epeiric seas. Geological Association of Canada Special Paper, v. 48, 406 pp.

Pruss, S.B., Finnegan, S., Fischer, W.W. and Knoll, A.H., 2010, Carbonates in skeleton-poor seas: new insights from Cambrian and Ordovician strata of Laurentia. Palaios, v. 25, pp. 73-84.

Rong, J.-Y. and Chen, X., 1986, A big event of latest Ordovician in China In: Walliser, O.H. (ed.), Global Bio-Events, Lecture Notes in Earth Sciences, v. 8, pp. 127-131.

Rong, J.-Y. and Harper, D.A.T., 1988, A global synthesis of the latest Ordovician Hirnantian brachiopod faunas. Transactions of the Royal Society of Edinburgh: Earth Sciences, v. 79, pp. 383-402.

Rong, J.-Y. and Harper, D.A.T., 1999, Brachiopod survival and recovery from the latest Ordovician mass extinctions in South China. Geological Journal, v. 34 , pp. $321-348$

Rong, J.-Y. and Chen, X., 1986, A big event of latest Ordovician in China, in Walliser, O.H. (ed.), Global Bio-Events, Lecture Notes in Earth Sciences, v. 8, pp. 127-131. Saltzman, M.R., Young, S.A., Kump, L.R., Gill, B.C., Lyons, T.W. and Runnegar, B. 2011, Pulse of atmospheric oxygen during the late Cambrian. PNAS, v. 108, pp. 3876-3881.

Schmitz, B., Harper, D.A.T., Peucker-Ehrenbrink, B., Stouge, S., Alwmark, C., Cronholm, A., Bergström, S.M., Tassinari, M. and Wang, X.F., 2008, Asteroid breakup linked to the Great Ordovician Biodiversification Event. Nature Geoscience, v. 1, pp. 49-53.

Sepkoski Jr., J.J., 1981, A factor analytical description of the Phanerozoic marine fossil record. Paleobiology, v. 7, pp. 36-53.

Servais,T., Lehnert,O., Li,J., Mullins,G.L., Munnecke,A., Nützel,A. and Vecoli,M.,2008,The Ordovician Biodiversification: revolution in the oceanic trophic chain. Lethaia, v. 41, pp. 99-109.

Servais, T., Harper, D.A.T., Li, J., Munnecke, A., Owen, A.W. and Sheehan, P.M., 2009, Understanding the Great Ordovician Biodiversification Event (GOBE): Influences of paleogeography, paleoclimate, or paleoecology? GSA Today, v. 19, pp. 4-7.

Servais, T., Owen, A.W. (eds), 2010, Early Palaeozoic Palaeoenvironments. Palaeogeography, Palaeoclimatology, Palaeoecology, v. 294, pp. 95-247.

Servais, T., Owen, A.W., Harper, D.A.T., Kröger, B. and Munnecke, A., 2010, The Great Ordovician Biodiversification Event (GOBE): the palaeoecological dimension. Palaeogeography, Palaeo-climatology, Palaeoecology, v. 294, pp. 99-119.

Sheehan, P.M., 2001a, History of marine diversity. Geological Journal, v. 36, pp. 231-249.

Sheehan, P.M., 2001b, The Late Ordovician mass extinction. Annual Reviews of Earth and Planetary Sciences, v. 29, pp. 331-364. 
Tripati, A.K., Eagle, R.A., Thiagarajan, N., Gagnon, A.C., Bauch, H., Halloran, P.R., and Eiler, J.M., 2010, ${ }^{13} \mathrm{C}-{ }^{18} \mathrm{O}$ isotope signatures and 'clumped isotope' thermometry in foraminifera and coccoliths. Geochimica et Cosmochimica Acta, v. 74, pp. 5697-5717.

Trotter, J.A., Williams, I.S., Barnes, C.R., Lécuyer, C. and Nicoll, R.S., 2008, Did cooling oceans trigger Ordovician biodiversification? Evidence from conodont thermometry. Science, v. 321, pp. 550-554

Van Roy. P., Orr, P.J., Botting, J.P., Muir, L.A., Vinther, J., Lefebvre, B., el Hariri, K., and Briggs, D.E.G., 2010, Ordovician faunas of Burgess Shale type. Nature, v. 465, pp. 215-218.

Vandenbroucke, T.R.A., Armstrong, H.A., Williams, M., Zalasiewicz, J. and Sabbe, K., 2009, Ground-truthing Late Ordovician climate models using the paleobiogeography of graptolites. Palaeoceanography, v. 24, pp. 119.

Vandenbroucke, T.R.A., Armstrong, H.A., Williams, M., Sabbe, K., Zalasiewicz, J.A., Nõlvak, J. and Verniers, J., 2010a, Epipelagic chitinozoan biotopes map a steep latitudinal temperature gradient for earliest Late Ordovician seas: implications for a cooling Late Ordovician climate. Palaeogeography, Palaeoclimatology, Palaeoecology, v. 294, pp. 202-219.

Vandenbroucke, T.R.A., Armstrong, H.A., Williams, M., Paris, F., Zalasiewicz, J.A., Sabbe, K., Nõlvak., J., Challands, T.J., Verniers, J., and Servais, T., 2010b, Polar front shift and atmospheric CO2 during the glacial maximum of the Early Paleozoic Icehouse. PNAS, v. 107, pp. 1498314986 .
Walker, L.J., Wilkinson, B.H. and Ivany, L.C., 2002, Continental drift and Phanerozoic carbonate accumulation in shallow-shelf and deep-marine settings. The Journal of Geology, v. 110, pp. 75-87.

Walliser, O. (ed.), 1986, Global events and event stratigraphy in the Phanerozoic. Springer Verlag, 333pp.

Webby, B.D., 2002, Patterns of Ordovician reef development, in Kiessling, W., Flügel, E., and Golonka, J., eds., Phanerozoic Reef Patterns: SEPM Special Publication, v. 72, pp. 129-179.

Webby, B.D., Droser, M.L., Paris, F. and Percival, I.G. (eds), 2004a, The Great Ordovician Biodiversification Event. Columbia University Press, New York, 484p.

Webby, B.D., Cooper, R.A., Bergström, S.M. and Paris, F., 2004b, Stratigraphic framework and timeslices, in Webby,B.D., Droser,M.L., Paris,F. and Percival,I.G. (eds),The Great Ordovician Biodiversification Event. Columbia University Press, New York, pp. 41-47.

Williams, A., 1973, Distribution of brachiopod assemblages in relation to Ordovician palaeogeography. Special Papers in Palaeontology, v. 12, pp. 241-269.

Wood, R.A., 2011, Paleoecology of the earliest skeletal metazoan communities: Implications for early biomineralization. Earth-Science Reviews, v. 106, pp. 184-190.

Young, S.A., Saltzman, M. R., Ausich, W.I., Desrochers A. and Kaljo, D., 2010, Did changes in atmospheric $\mathrm{CO}_{2}$ coincide with latest Ordovician glacial-interglacial cycles? Palaeogeography, Palaeoclimatology, Palaeoecology, v. 296, pp. 376-388.

\section{Episodes is your window to the world. Subscribe today!}

\section{Episodes}

Name

(please print)

Address

City $\_$State/Province
Country $\_$Zip/Postal Code

Please begin my subscription from the year

To start your subscription, fill this form and mail to:

\section{Episodes}

Geological Society of India

No.63, 12th Cross, Basappa Layout

Gavipuram P.O., P.O. Box No. 1922

Bangalore - 560 019, INDIA

Telefax: +91-080-26613352; Phone:+91-080-22422943

Email: episodes.journal@gmail.com
Payment may be made by:

- Checks/Bank draft (US \$ only) payable to: 'Geological Society of India A/C Episodes'

- Bank Transfer:

'Geological Society of India A/C Episodes'

Bank Name : Canara Bank, Hanumanthanagar Branch Bangalore - 560019

S.B. A/C No. : 0472101044517

Bank Code : 560015020

Swift Code : CNRBINBBLFD

Annual Subscription rate: US $\$ 30$ 